\title{
Financial Aid and Higher Education Dropout in Colombia
}

\author{
Lesly Katheryne Durán Cabieles ${ }^{1}$, Jaime Andrés Sarmiento Espinel ${ }^{2}$, Adriana Carolina Silva Arias ${ }^{3}$ \\ ${ }^{1}$ Universidad Militar Nueva Granada, Bogotá, Colombia, gesma@unimilitar.edu.co \\ ${ }^{2}$ Universidad Militar Nueva Granada, Bogotá, Colombia, jaime.sarmiento@unimilitar.edu.co \\ ${ }^{3}$ Universidad Militar Nueva Granada, Bogotá, Colombia, adriana.silva@unimilitar.edu.co
}

\begin{abstract}
One of the reasons for a government to support an education system is its role in productivity growth of its citizens and nation's economic development. Although in some less-developed countries, such as Colombia, there is low levels of non-participation in primary and secondary education, there are high levels of dropout in higher education. The Colombian educational loan system experienced some changes to comply the 2010 National Agreement to Reduce Dropout. This paper analyzes the behavior of higher education dropout and its relation with financial aid before and after this Agreement. By means of a discrete-time logit model and a difference-in-differences approach, there is evidence that loans conditions after the National Agreement would not have achieved its goal.
\end{abstract}

KEYWORDS: dropout, duration analysis, financial aid, higher education

\section{Introduction}

The accumulation of human capital has effects on productivity, economic growth and quality of life of a country (Barro 1991, Mankiw, Romer, and Weil 1992, Sala-I-Martin, Doppelhofer, and Miller 2004). A common strategy adopted by some countries to promote investments in human capital has been to strengthen their education system (Burton 1969). However, the absence of studies has not only direct effects on the student but also implications in society (Gartner Isaza, Dussán Lubert, and Montoya 2016). With respect to higher education, Latin America has had a high percentage of dropout (Espíndola and León 2002, Henríquez and Escobar 2016, Donoso and Schiefelbein 2007, Velázquez Narváez and González Medina 2017, Estrada-Ruiz 2015). In Colombia, the dropout rate was approximately 50\% in 2000 , with a slowing downward trend over time (Pardo Jaime 2016, MEN, 2009, Gartner Isaza, Dussán Lubert, and Montoya 2016).

The Colombian government established in 2010 a national agreement that involved the participation of different education system actors. Its purpose were to reduce higher education dropout, from $12.9 \%$ in 2010 to 9\% in 2014, and strengthen the relationship between education quality and students permanence (MEN 2012). Among its strategies, it was sought to relax loans conditions and strengthen the institution in charge of the educational credit system, the Colombian Institute of Educational Credit and Abroad Technical Studies (ICETEX, by its Spanish acronym). In this way, it is possible to reduce not only entry barriers to higher education but also educational inequality opportunities, bringing individual and social benefits (Chen and DesJardins 2008, Chen 2008, Reuterberg and Svensson 1983). There was an increase of $96 \%$ in the number of education loans given between 2010 and 2012. In this sense, there was an increase in educational loans and renewal transfers to students with low socioeconomic stratum between 2010 and 2011 (Figure 1).

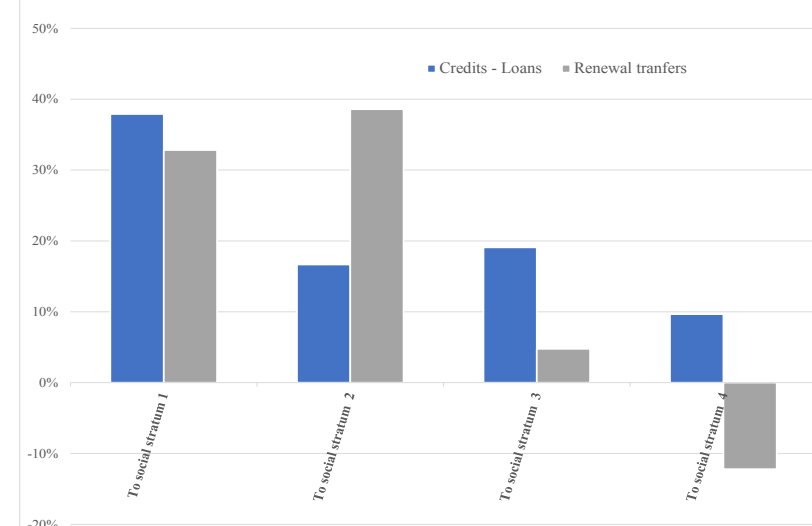

Figure 1. ICETEX loans and renewal transfers by socioeconomic stratum between 2010 and 2011 
In this paper we analyzed - through a discrete survival model - whether these changes on financial aid conditions have influenced dropout behavior on Colombian undergraduate programs. For this, we use data between 2000 and 2015 from the System of Prevention and Analysis of the Dropout from the Higher Education Institutions (SPADIES, by its Spanish acronym).

The paper is organized as follows. Section 2 briefly describes the methodology employed, a discrete-time logit model and a difference-in-differences approach to identify the impact of changes in the conditions of educational loans by the 2010 National Agreement on students' probability of dropping out. The data is described in Section 3. Our main findings are summarized in Section 4 and some concluding remarks are expressed in Section 5.

\section{Empirical strategy}

In this paper we analyzed undergraduate dropout behavior under 2010 Colombian government initiative to reduce it. Particularly, we compare dropout behavior of students who enrolled before the first semester of 2010 (2010h1) with students who enrolled after the second semester of 2010 (2010h2). Following Belot, Canton, and Webbink (2007), we use a difference-in-differences approach. The first difference corresponds to the difference in behavior of students before and after the agreement. The second one tries to isolate the effect of changes in the educational loan conditions form other changes that could have been occurred before and after the agreement. As a control group we used students without educational loans. We expect that the agreement has less of an effect on students without a credit than on students with it.

The discrete-time logit model to estimate is:

$\log \left(\frac{p_{t i}}{1-p_{t i}}\right)=\alpha_{1} D_{t i}+\beta X_{t i}+\delta$ Year $_{i}+\lambda$ Icetex $_{t i}+\gamma$ Year $\times$ Icetex $_{t i}+\varepsilon_{i}$

where,

$p_{t i}$ : probability of student $i$ of dropout during interval $t$

$D_{t i}$ : vector of functions of the cumulative duration by interval $t$

$X_{t i}$ : vector of covariates

Year $=$ Time dummy corresponding to the year of enrolment $(0=$ before $2010 \mathrm{~h} 1,1=$ after $2010 \mathrm{~h} 2)$

Icetex $=$ Dummy of financial aid $(1=$ student had a loan, $0=$ on other case $)$

$\varepsilon_{i}=$ Error term

In this model, $\delta$ measures the overall effect of time on the log-odds, $\lambda$ the effect of financial aid and $\gamma$ the impact of the agreement.

\section{Data}

We used SPADIES data as main source of information. Table 1 presents the descriptive statistics for the set of covariates used in the model.

Table 1. Covariates

\begin{tabular}{|l|r|r|r|r|}
\hline \multicolumn{1}{|c|}{ Variables } & \multicolumn{2}{c|}{ Before 2010h1 } & \multicolumn{2}{c|}{ After 2010h2 } \\
\hline & Without loans & \multicolumn{1}{c|}{ With loans } & \multicolumn{1}{c|}{ Without loans } & \multicolumn{1}{c|}{ With loans } \\
\hline Individual characteristics & & & & \\
\hline Age & 21.101 & 20.895 & 21.836 & 20.709 \\
\hline & $(4.150)$ & $(3.779)$ & $(4.528)$ & $(3.714)$ \\
\hline Gender & & & & \\
\hline Male & 0.483 & 0.517 & 0.496 & 0.496 \\
\hline
\end{tabular}




\begin{tabular}{|c|c|c|c|c|}
\hline Female & 0.517 & 0.483 & 0.504 & 0.504 \\
\hline \multicolumn{5}{|l|}{ Academic performance } \\
\hline \multirow[t]{2}{*}{ Number of inscribed courses } & 4.866 & 5.561 & 4.74 & 5.235 \\
\hline & $(3.501)$ & $(4.267)$ & $(3.306)$ & $(3.202)$ \\
\hline \multirow[t]{2}{*}{ Number of failed courses } & 1.601 & 1.289 & 1.834 & 1.645 \\
\hline & $(2.119)$ & $(1.946)$ & $(2.293)$ & $(2.253)$ \\
\hline \multirow[t]{2}{*}{ Score in the secondary education national exam } & 63.756 & 68.67 & 60.336 & 72.96 \\
\hline & $(26.732)$ & $(23.994)$ & $(28.339)$ & $(23.511)$ \\
\hline \multirow[t]{2}{*}{ Semesters before start undergrad } & 3.529 & 3.302 & 6.716 & 4.616 \\
\hline & $(4.642)$ & $(4.323)$ & $(7.557)$ & $(5.842)$ \\
\hline \multirow[t]{2}{*}{ Number of semesters } & 5.128 & 5.197 & 2.909 & 3.043 \\
\hline & $(4.145)$ & $(3.439)$ & $(1.779)$ & $(1.787)$ \\
\hline \multicolumn{5}{|l|}{ Social stratum } \\
\hline 1 & 0.128 & 0.145 & 0.188 & 0.208 \\
\hline 2 & 0.354 & 0.388 & 0.381 & 0.365 \\
\hline 3 & 0.265 & 0.264 & 0.268 & 0.277 \\
\hline 4 & 0.039 & 0.035 & 0.061 & 0.07 \\
\hline 5 & 0.016 & 0.014 & 0.024 & 0.024 \\
\hline 6 & 0.008 & 0.005 & 0.013 & 0.009 \\
\hline Unclassified households & 0 & 0 & 0 & 0 \\
\hline Do not report & 0.19 & 0.149 & 0.066 & 0.048 \\
\hline \multicolumn{5}{|l|}{ Level household income (in minimum wages) } \\
\hline Less than 1 & 0.131 & 0.142 & 0.175 & 0.177 \\
\hline Between 1 and 2 & 0.342 & 0.36 & 0.416 & 0.397 \\
\hline Between 2 and 3 & 0.226 & 0.226 & 0.207 & 0.213 \\
\hline Between 3 and 5 & 0.169 & 0.165 & 0.118 & 0.128 \\
\hline Between 5 and 7 & 0.071 & 0.063 & 0.041 & 0.046 \\
\hline More than 7 & 0.062 & 0.044 & 0.043 & 0.038 \\
\hline \multicolumn{5}{|l|}{ Mother's education level } \\
\hline Does not report/Without education & 0.034 & 0.021 & 0.024 & 0.017 \\
\hline Primary & 0.209 & 0.216 & 0.234 & 0.208 \\
\hline Secondary & 0.384 & 0.37 & 0.435 & 0.415 \\
\hline Technical/technologist & 0.17 & 0.186 & 0.125 & 0.145 \\
\hline Undergrad & 0.203 & 0.207 & 0.183 & 0.213 \\
\hline \multicolumn{5}{|l|}{ Academic support } \\
\hline No & 0.971 & 0.958 & 0.913 & 0.918 \\
\hline Yes & 0.029 & 0.042 & 0.087 & 0.082 \\
\hline \multicolumn{5}{|l|}{ Financial support } \\
\hline No & 0.882 & 0.787 & 0.825 & 0.761 \\
\hline Yes & 0.118 & 0.213 & 0.175 & 0.239 \\
\hline \multicolumn{5}{|l|}{ Juridical nature } \\
\hline National & 0.195 & 0.092 & 0.203 & 0.111 \\
\hline Departmental & 0.221 & 0.058 & 0.192 & 0.056 \\
\hline Municipal & 0.034 & 0.009 & 0.032 & 0.007 \\
\hline Corporation & 0.283 & 0.466 & 0.307 & 0.438 \\
\hline
\end{tabular}




\begin{tabular}{|l|r|r|r|r|}
\hline Foundation & 0.267 & 0.375 & 0.265 & 0.388 \\
\hline Academic programs & 95.427 & 83.011 & 93.398 & 85.275 \\
\hline & $(94.995)$ & $(66.191)$ & $(91.782)$ & $(71.839)$ \\
\hline Quality accredited Institution & & & & \\
\hline No & 0.534 & 0.554 & 0.622 & 0.557 \\
\hline Yes & 0.466 & 0.446 & 0.378 & 0.443 \\
\hline Age of the high institutions & 50.329 & 47.285 & 45.981 & 47.014 \\
\hline & $(16.584)$ & $(16.553)$ & $(16.789)$ & $(17.064)$ \\
\hline Context & & & & \\
\hline Inflation & 0.047 & 0.044 & 0.030 & 0.029 \\
\hline & $(0.018)$ & $(0.016)$ & $(0.009)$ & $(0.008)$ \\
\hline
\end{tabular}

Note: Standard deviations in parentheses

\section{Results}

Using SPADIES sample, we estimated equation (1). We found that mostly all covariates are statistically significant at the $1 \%$ level. Table 2 presents estimated marginal effects of the difference-in-differences approach. Time and financial aid had a negative effect on dropout. In particular, dropout probability decreased on average 0.2 percentage points after 2010, and 1.2 percentage points due to changes on loans conditions. However, once it was controlled by other factors, dropout probability increased in 2 percentage points because of the National Agreement.

Table 2. Effects of National Agreement on dropout rates from discrete-time logit model

\begin{tabular}{|l|r|}
\hline \multicolumn{1}{|c|}{ Variable } & Estimate \\
\hline Time & $-0.002 \quad * * *$ \\
\hline & $(0.000)$ \\
\hline Financial aid & $-0.012 \quad * * *$ \\
\hline & $(0.000)$ \\
\hline Agreement & $0.020 * * *$ \\
\hline & $(0.001)$ \\
\hline
\end{tabular}

Note: Standard errors in parentheses. *Significant at $10 \%$ level, ** Significant at $5 \%$ level, *** Significant at $1 \%$ level

\section{Concluding remarks}

The 2010 National Agreement to Reduce Dropout was a Colombian government strategy to bring support to students in risk of not continue their undergrad education. One of its principal strategies was to offer more credits with more favorable conditions for undergrad students. However, the effect does not seem to comply its objective. Instead, it seems that the initiative augmented the probability of dropout.

One of the possible explanations of our results is that there was a selection bias of the students who benefited from this policy, since they were the students with unfavorable economic conditions with whom a greater probability to dropout is related. This would imply that the financial aid offered through the government strategy was not enough to guarantee the permanence of the students.

In future research, it would be relevant to improve the identification strategy of the students who benefited from this policy and students with similar characteristics who did not benefit from this policy. In this way, any change in the trend of dropout could be associated with this strategy.

\section{Funding}

Product derived from the research project INV-ECO 2581 financed by the Vice Presidency for Research of the Universidad Militar Nueva Granada - 2018 term. 


\section{References}

Barro, Robert J. 1991. "Economic growth in a cross section of countries." The Quarterly Journal of Economics 106 (2): 407443. Doi: $10.2307 / 2937943$.

Belot, Michèle, Erik Canton, and Dinand Webbink. 2007. "Does reducing student support affect scholastic performance? Evidence from a Dutch reform." Empirical Economics 32 (2): 261-275. Doi: 10.1007/s00181-006-0094-1.

Burton, Leone. 1969. "Education and development." British Journal of Educational Studies 17 (2): 129-145. Doi: $10.2307 / 3119256$.

Chen, Rong. 2008. "Financial aid and student dropout in higher education: A heterogeneous research approach." In Higher Education, edited by John C. Smart, 209-239. Dordrecht: Springer Netherlands.

Chen, Rong, and Stephen L. DesJardins. 2008. "Exploring the effects of financial aid on the gap in student dropout risks by income level." Research in Higher Education 49 (1): 1-18. Doi: 10.1007/s11162-007-9060-9.

Donoso, Sebastián, and Ernesto Schiefelbein. 2007. "Analysis of explanatory models of student retention in the university: a vision from the social inequality (Análisis de los modelos explicativos de retención de estudiantes en la universidad: una visión desde la desigualdad social)." Estudios pedagógicos (Valdivia) 33 (1): 7-27.

Espíndola, Ernesto, and Arturo León. 2002. "Dropping out of school in Latin America: a priority issue for the regional agenda (La deserción escolar en América Latina: un tema prioritario para la agenda regional)." Revista Iberoamericana de Educación 30: 39-62.

Estrada-Ruiz, and Marcos Jacobo. 2015. "Young women who drop out of secondary education: turns and points of no return (Las jóvenes que desertan de la educación media: virajes y puntos de no retorno)." Revista Latinoamericana de Ciencias Sociales, Niñez y Juventud 13 (2): 995. Doi: 10.11600/1692715x.13231190214.

Gartner Isaza, Lorena, Carmen Dussán Lubert, and Diana Marcela Montoya. 2016. "Characterization of the student dropout at the University of Caldas in 2009-2013 period. Analysis from the system for the prevention of the dropout of higher education-SPADIES (Caracterización de la Deserción Estudiantil en la Universidad de Caldas y el período 2009-2013. Análisis a partir del Sistema Para la Prevención de la Deserción de la Educación Superior-SPADIES)." Revista Latinoamericana de Estudios Educativos (Colombia) 12 (1): 132-158.

Henríquez, C, and R Escobar. 2016. "Building a model for early warning detection of students at risk of dropping out from the Metropolitan University of Educational Sciences (Construcción de un modelo de alerta temprana para la detección de estudiantes en riesgo de deserción de la Universidad Metropolitana de Ciencias de la Educación)." Revista Mexicana de Investigación Educativa 21 (71): 1221-1248.

Mankiw, N Gregory, David Romer, and David N Weil. 1992. "A contribution to the empirics of economic growth." The Quarterly Journal of Economics 107 (2): 407-437. Doi: 10.2307/2118477.

Ministerio de Educación Nacional. 2009. Colombian student dropout rate in higher education. Methodology of monitoring, diagnosis and elements for its prevention (Deserción estudiantil en la educación superior colombiana. Metodología de seguimiento, diagnóstico y elementos para su prevención). Bogotá: Imprenta Nacional de Colombia.

Ministerio de Educación Nacional. 2012. Policy and strategies to encourage permanence and graduation in higher education 2013-2014 (Política y estrategias para incentivar la permanencia y graduación en educación superior 2013-2014).

Pardo Jaime, Leonardo. 2016. "Career Crisis Assessment Tool (Instrumento de Evaluación de Crisis de Carrera - CRICA)." Revista de Psicología GEPU 7 (1): 268.

Reuterberg, Sven-Eric, and Allan Svensson. 1983. "The importance of financial aid: The case of higher education in Sweden." Higher Education 12 (1): 89-100. Doi: 10.1007/BF00140274.

Sala-I-Martin, Xavier, Gernot Doppelhofer, and Ronald I Miller. 2004. "Determinants of long-term growth: A Bayesian Averaging of Classical Estimates (BACE) Approach." The American Economic Review 94 (4):813-835. Doi: $10.1257 / 0002828042002570$.

Velázquez Narváez, Yolanda, and Mario Alberto González Medina. 2017. "Factors associated with retention of college students: UAMM case-UAT (Factores asociados a la permanencia de estudiantes universitarios: caso UAMM-UAT)." Revista de la Educación Superior 46 (184): 117-138. Doi: 10.1016/j.resu.2017.11.003. 